https://doi.org/10.18778/1509-877X.2019.04.01

Włodzimierz Nykiel*

\title{
PRAWA PODATNIKA A STANOWIENIE PRAWA PODATKOWEGO - WYBRANE ZAGADNIENIA
}

\begin{abstract}
Streszczenie. Dobre funkcjonowanie mechanizmów finansowych państwa wymaga sprawnego prowadzenia polityki finansowej, w tym polityki podatkowej. Przewidywalność zmian prawa podatkowego stanowiących wyraz realizacji polityki znanej podatnikom jest zgodna z zasadą pewności prawa, gdyż istotnie redukuje ujemne konsekwencje braku stabilności.

Jak wiadomo, posiedzenia Sejmu i Senatu są jawne. Jawne powinny być jednak także projekty przepisów prawa podatkowego, a nawet założenia owe projekty poprzedzające. Z jednej strony umożliwiłoby to, a co najmniej znacznie ułatwiło, przeprowadzenie odpowiednich konsultacji publicznych, z drugiej zaś redukowało niepewność podatników co do przyszłego prawa. W toku prac nad projektem należy dbać o poprawność języka prawnego i szanować zasady techniki prawodawczej.

Konsultowanie i opiniowanie projektów przepisów podatkowych przez różne podmioty, w tym przez ekspertów, ma olbrzymie znaczenie dla prac ustawodawczych. Prowadzenie konsultacji z udziałem podatników, przedstawicieli organizacji społecznych, samorządowych i gospodarczych oraz samorządów zawodowych ma wpływ na jakość prawa i sprzyja odpowiedniemu wyważeniu interesu publicznego i prywatnego w prawie podatkowym.

W przypadku niezrozumiałego przepisu, podatnika winna chronić zasada in dubio pro tributario. Przepis taki nie może być także podstawą zastosowania wobec podatnika sankcji.

Do zasad podatkowych mających największe znaczenie z punktu widzenia praw podatnika należy zasada pewności. Pewność i bezpieczeństwo prawne podatnika ściśle wiążą się z zasadą lex retro non agit. Ważne są też zasady: ochrony praw nabytych i ochrony interesów w toku.

Warto podkreślić, że projekt ustawy Karta Praw Podatnika wniesiony niedawno do Sejmu niemało miejsca poświęca przepisom dotyczącym stanowienia prawa podatkowego.

Obserwacja praktyki dowodzi, że takie przepisy są potrzebne, gdyż przyczyniłyby się z jednej strony do poprawy jakości naszego prawa podatkowego, z drugiej zaś do wzmocnienia ochrony praw podatnika.
\end{abstract}

Słowa kluczowe: prawa podatnika, karta praw podatnika, tworzenie prawa podatkowego, legislacja, zasady tworzenia prawa

* Profesor nauk prawnych, kierownik Katedry Prawa Podatkowego, Wydział Prawa i Administracji, Uniwersytet Łódzki, e-mail: wnykiel@wpia.uni.lodz.pl 
1. Jak wiadomo, prawa podatnika zaliczane są do praw człowieka. Zmierzają one do ograniczenia władztwa państwa w celu ustanowienia sui generis równowagi między potrzebami dochodowymi państwa a prawami jednostki ${ }^{1}$. Cechuje je duża różnorodność ${ }^{2}$. Prawa podatnika nawiązują do wielu zasad podatkowych ${ }^{3}$.

Prawa podatnika zawarte są w wielu aktach prawa podatkowego zarówno ogólnego, jak i szczegółowego. Występują one również poza prawem podatkowym sensu stricto, w konstytucjach poszczególnych państw, w prawie Unii Europejskiej, a także w Europejskiej Konwencji Praw Człowieka.

W wielu państwach uznano, że w celu poprawy skuteczności ochrony praw podatnika należy uchwalić odrębną ustawę wyłącznie temu poświęconą lub opracować odrębny dokument niemający waloru aktu normatywnego. Te akty normatywne i dokumenty niemające takiego charakteru często są nazywane kartami praw podatnika ${ }^{4}$.

W Polsce stan prawny w zakresie praw podatnika i ich ochrony jest wysoce niezadowalający ${ }^{5}$. Brakuje nam zarówno nowej ordynacji podatkowej, jak i karty praw podatnika, a bez wątpienia unormowania odnoszące się do praw podatnika zawarte w starej ordynacji podatkowej są zbyt skromne.

Prace nad nową ordynacją podatkową podjęto w 2014 r. Powstał nawet projekt tego aktu opracowany przez zespół pod kierownictwem prof. L. Etela. Ministerstwo Finansów wprowadziło do projektu sto kilkadziesiąt poprawek. Rządowy projekt ustawy Ordynacja podatkowa trafił do Sejmu 4 czerwca 2019 r. (druk nr 3517/VIII kadencja), po pierwszym czytaniu skierowano go do Komisji Finansów Publicznych. Po rozpoczęciu

1 D. Bentley, Taxpayers' Rights: Theory, Origin and Implementation, Kluwer Law International 2007, s. 56.

2 B. Brzeziński, Koncepcja praw podatnika i ich ochrony jako przedmiot badań naukowych, „Kwartalnik Prawa Podatkowego” 2005, nr 1, s. 9 i n.

3 Por. A. Gomułowicz, Zasady podatkowe wczoraj i dziś, Warszawa 2001; D. Bentley Taxpayers' Rights..., s. 60 i n.

4 Z. Kmieciak, Procesowe gwarancje ochrony interesu podatnika, „Kwartalnik Prawa Podatkowego" 2000, nr 1, s. 15 i n.; P. Baker, Taxpayers' Charters and a Taxpayers' Charter for Europe, [w:] Protection of Taxpayer's Rights, European, International and Domestic Tax Law Perspective, red. W. Nykiel, M. Sęk, Warszawa 2009, s. 130 i n.; M. Sęk, Karta Praw Podatnika $w$ polskim systemie podatkowym $w$ świetle doświadczeń zagranicznych, „Kwartalnik Prawa Podatkowego" 2018, nr 1, s. 71 i n.

5 M. Wilk, Potrzeba wprowadzenia Karty Praw Podatnika w Polsce, „Kwartalnik Prawa Podatkowego" 2018, nr 1, s. 103-104. 
nowej kadencji projekt nie został ponownie wniesiony i żadne prace w tym zakresie się nie toczą.

Projekt ustawy Karta Praw Podatnika, nad którym prace rozpoczęto w 2017 r., został wniesiony do Sejmu przez grupę posłów PO 26 kwietnia 2019 r. ${ }^{6}$ Upływ kadencji sprawił, że prace nad tym projektem zostały przerwane. Został on ponownie wniesiony przez grupę posłów KO 12 grudnia 2019 r., a 8 stycznia 2020 r. został skierowany do pierwszego czytania ${ }^{7}$.

Niestety szanse na uchwalenie w najbliższym czasie nowej ordynacji podatkowej lub karty praw podatnika są znikome.

Wydawać by się mogło, że badanie praw podatnika w danym kraju winno polegać na ustaleniu, jakie prawa podatnikowi przyznają akty prawne prawa wewnętrznego oraz akty prawa europejskiego i międzynarodowego, a także jak wygląda ich realizacja w praktyce. Bez wątpienia taka analiza przyniosłaby odpowiedź na pytanie, jaka jest sytuacja w zakresie praw podatnika w badanym kraju. Jednakże byłaby to odpowiedź niepełna, gdyż poważny wpływ na prawa podatnika mają też procesy tworzenia prawa, w tym przede wszystkim prawa podatkowego. Owemu wpływowi poświęcony jest właśnie niniejszy artykuł. Przedmiotem rozważań i analiz będzie tu szeroko rozumiany proces tworzenia prawa podatkowego ${ }^{8}$.

2. Dobre funkcjonowanie mechanizmów finansowych państwa wymaga sprawnego prowadzenia polityki finansowej, w tym polityki podatkowej ${ }^{9}$. Wyraźnie sformułowana, kompleksowa, wewnętrznie spójna polityka podatkowa jest korzystna także dla podatników. Przewidywalność zmian prawa podatkowego stanowiących wyraz realizacji polityki znanej podatnikom jest zgodna $\mathrm{z}$ zasadą pewności prawa, gdyż istotnie redukuje ujemne konsekwencje braku stabilności. Inaczej dzieje się wówczas, gdy państwo nie ma klarownej wizji przeobrażeń prawa podatkowego, a przepisy są uchwalane bez żadnego planu przede wszystkim w reakcji na przebieg

${ }^{6}$ Poselski projekt ustawy - Karta Praw Podatnika, druk sejmowy nr 3458/VIII kadencja, https://www.sejm.gov.pl/Sejm8.nsf/druk.xsp?nr=3458 (dostęp: 4.02.2020).

7 Poselski projekt ustawy - Karta Praw Podatnika, druk sejmowy nr 137/IX kadencja, http://www.sejm.gov.pl/Sejm9.nsf/druk.xsp?nr=137 (dostęp: 4.02.2020).

${ }^{8} \mathrm{Na}$ temat faz procesu legislacyjnego zob. C. Kosikowski, Ustawa podatkowa, Warszawa 2006, s. 96 i n.

9 Na temat pojęć: „polityka”, „polityka podatkowa”, „polityka prawa” zob. J. Wróblewski, Zasady tworzenia prawa, Warszawa 1989, s. 35 i n.; J. Serwacki, Polityka podatkowa, [w:] Prawo podatkowe. Teoria. Instytucje. Funkcjonowanie, red. B. Brzeziński, Toruń 2009, s. 529 i n.; B. Brzeziński, Prawo podatkowe. Zagadnienia teorii i praktyki, Toruń 2017, s. 209 i n. 
zdarzeń społecznych i gospodarczych. Prowadzi to do wielu niekorzystnych następstw, m.in. do częstych nowelizacji tego samego aktu prawnego.

W Polsce niestety nie ma długookresowej, ani nawet średniookresowej polityki podatkowej, brakuje wizji systemu podatkowego i jego zmian w kilkuletnim okresie.

Jak głosi art. 113 Konstytucji Rzeczypospolitej Polskiej ${ }^{10}$ : „Posiedzenia Sejmu są jawne”. Treść tego przepisu odnosi się do posiedzeń plenarnych izby. Posiedzenia plenarne, podczas których rozpatrywane są projekty przepisów podatkowych, są więc oczywiście jawne. Przepis ten stosuje się też odpowiednio do Senatu. Jawne powinny być jednak także projekty przepisów prawa podatkowego, a nawet założenia owe projekty poprzedzające. Z jednej strony umożliwiłoby to bowiem, a co najmniej znacznie ułatwiło, przeprowadzenie odpowiednich konsultacji społecznych, z drugiej zaś redukowało niepewność podatników co do przyszłego prawa.

Konsultowanie i opiniowanie projektów przepisów podatkowych przez różne podmioty, w tym przez ekspertów, ma olbrzymie znaczenie dla prac ustawodawczych. Prowadzenie konsultacji z udziałem podatników, przedstawicieli organizacji społecznych, samorządowych i gospodarczych oraz samorządów zawodowych sprzyja odpowiedniemu wyważeniu interesu publicznego i prywatnego w prawie podatkowym. Podatnicy, bezpośrednio bądź pośrednio, jako adresaci przepisów podatkowych winni mieć prawo do uczestniczenia w konsultacjach. Konsultowanie i opiniowanie projektów przez ekspertów podnosi jakość merytoryczną i formalną projektów ${ }^{11}$, a nie ulega wątpliwości, że jakość unormowań prawa podatkowego jest dziś naszym olbrzymim problemem.

W Polsce ostatnio niestety unika się konsultacji. Sposobem na ich uniknięcie jest m.in. zgłoszenie danego projektu jako projektu poselskiego, który konsultacji nie wymaga. Oddzielną kwestią jest to, czy projekt zgłoszony jako poselski został rzeczywiście opracowany przez posłów. Wątpliwości rodzą się np. wówczas, gdy na posiedzeniu komisji jakiś poseł zadaje pytanie posłowi reprezentującemu wnioskodawców, zapytany milczy, a odpowiada przedstawiciel ministerstwa, i taka sytuacja powtarza się wielokrotnie.

10 Konstytucja Rzeczypospolitej Polskiej z dnia 2 kwietnia 1997 r. (Dz.U. z 1997 r., Nr 78, poz. 483), dalej: Konstytucja RP.

11 P. Baker, P. Pistone, Taxpayers' Rights, General Report, IFA 2015, s. 68; R. Mastalski, Tworzenie prawa podatkowego a jego stosowanie, Warszawa 2015, s. 66 i n. 
W Zaleceniu Rady w sprawie krajowego programu reform Polski na 2019 r. oraz zawierającym opinię Rady na temat przedstawionego przez Polskę programu konwergencji na rok 2019 z 5 czerwca 2019 r. (s. 6-7) czytamy m.in.: „Prowadzenie efektywnego dialogu ze wszystkimi zainteresowanymi stronami przyczyniłoby się do poprawy jakości prawodawstwa oraz - dzięki ograniczeniu liczby potrzebnych nowelizacji - zwiększyłoby stabilność warunków prowadzenia działalności gospodarczej. Dlatego też zwiększenie roli konsultacji z partnerami społecznymi i konsultacji publicznych - w tym poprzez zapewnienie wystarczającego czasu na proces konsultacji, lepsze wykorzystanie opinii respondentów oraz ograniczenie do minimum przypadków wyłączenia ustaw z konsultacji - w znacznym stopniu przyczyniłoby się do zmniejszenia obciążeń administracyjnych wynikających z częstych zmian przepisów prawa oraz do zwiększenia inwestycji, a także wspierałoby zrównoważony wzrost gospodarczy w perspektywie długoterminowej”.

We współczesnych państwach jakość ustawodawstwa podatkowego jest powszechnie krytykowana ${ }^{12}$. Na tym nie najlepszym tle Polska w ostatnich kilku latach wyróżnia się negatywnie ${ }^{13}$.

Autorzy projektów nie szanują reguł rządzących językiem polskim. „Błędy gramatyczne, wielopiętrowe zdania, kaskadowe odesłania, nielogiczne definicje - tak wygląda projekt nowelizacji ustaw podatkowych w wersji przygotowanej przez Ministerstwo Finansów" - takie błędy i niedostatki jednego z bardzo obszernych projektów wskazywał prof. J. Bralczyk $^{14}$. „Zaplątanie sprzyja nielogiczności. Nielogiczność sprzyja niegramatyczności. A wszystko to łączy się ze sobą, tworząc niezrozumiałą, piętrową konstrukcję"15. W odniesieniu do tego samego projektu przedstawiciel Biura Legislacyjnego Kancelarii Sejmu podczas posiedzenia Komisji Finansów Publicznych zwracał uwagę na to, że „należy dokonać korekty kilkuset przecinków, żeby zapewnić poprawność językową tekstu.

12 W. Nykiel, M. Sęk, Standards, Trends and Challenges of National Tax Legislation, [w:] Tax Legislation. Standards, Trends and Challenges, red. W. Nykiel, M. Sęk, Warszawa 2015, s. 199 i n.

13 P. Strawiński, Compliance. Prowadzenie biznesu $w$ Polsce to brawura (wywiad z prof. A. Mariańskim, przewodniczącym Krajowej Rady Doradców Podatkowych), „Forbes" 26.03.2020, s. 108 i n.

14 K. Jędrzejewska, Prof. Bralczyk: Fiskus oblewa egzamin z języka polskiego (wywiad), Gazeta Prawna.pl, 17.09.2018.

15 Ibidem. 
Należy skorygować wiele odesłań, zapewnić równoległe brzmienie przepisów w ustawie o podatku dochodowym od osób fizycznych i w ustawie o podatku dochodowym od osób prawnych. Ponadto chcemy zaznaczyć, że projekt koliduje z innymi projektami nowelizującymi"16. Można zasadnie stwierdzić, że w takiej sytuacji naruszane są również podstawowe zasady techniki prawodawczej ${ }^{17}$.

Nie ma wątpliwości, że w przypadku niezrozumiałego przepisu, podatnika winna chronić zasada in dubio pro tributario ${ }^{18}$. Przepis taki nie może być też podstawą zastosowania wobec podatnika sankcji.

Zdrowy rozsądek, a także zasady techniki prawodawczej nakazują, by tytuł ustawy był adekwatny do jej treści. Zgodnie z tymi zasadami przedmiot ustawy ujęty w tytule winien być określony możliwie najzwięźlej $\mathrm{i}$ „w sposób adekwatnie informujący o jej treści"19. Okazuje się, że nawet tak oczywista reguła może zostać złamana. Oto w lipcu 2016 r. uchwalona została ustawa „o aktywizacji przemysłu okrętowego i przemysłów komplementarnych”20. Jej przedmiotem jest zryczałtowany podatek od wartości sprzedanej produkcji i tego podatku dotyczą przepisy ustawy. Tytuł ustawy nie ma więc nic wspólnego z jej rzeczywistym przedmiotem i treścią. Na tym tle można postawić pytanie, jak podatnik ma znaleźć tę ustawę w różnych bazach danych. Skala absurdu w tym przypadku jest lepiej widoczna, jeśli wyobrazimy sobie np., że ustawa o podatku dochodowym od osób fizycznych ma nowy tytuł, a mianowicie „ustawa o aktywizacji społecznej”.

Projektowi ustawy towarzyszy uzasadnienie, które w myśl art. 34 ust. 2 Regulaminu Sejmu ${ }^{21}$ powinno: „1) wyjaśniać potrzebę i cel wydania ustawy, 2) przedstawiać rzeczywisty stan w dziedzinie, która ma być unormowana, 3) wykazywać różnicę pomiędzy dotychczasowym a projektowanym

16 Kancelaria Sejmu, Biuro Komisji Sejmowych, Pełny zapis przebiegu posiedzenia Komisji Finansów Publicznych (nr 370) z dnia 17 października 2018 r., s. 12.

17 Por. np. \$\$ 5, 6 i 7 Załącznika „Zasady techniki prawodawczej” do Rozporządzenia Prezesa Rady Ministrów z dnia 20 czerwca 2002 r. w sprawie „Zasad techniki prawodawczej” (tekst jedn. Dz.U. z 2016 r., poz. 283).

18 Por. B. Brzeziński, W. Nykiel, Zasady ogólne prawa podatkowego, „Przegląd Podatkowy” 2002, nr 3; A. Mariański, Rozstrzyganie wątpliwości na korzyść podatnika. Zasada prawa podatkowego, Warszawa 2011.

19 Por. $\$ 18$ Zasad techniki prawodawczej.

20 Ustawa z dnia 6 lipca 2016 r. o aktywizacji przemysłu okrętowego i przemysłów komplementarnych (tekst jedn. Dz. U. z 2019 r., poz. 471).

21 Uchwała Sejmu Rzeczypospolitej Polskiej z dnia 30 lipca 1992 r. Regulamin Sejmu Rzeczypospolitej Polskiej (tekst jedn. M.P. z 2019 r., poz. 1028). 
stanem prawnym, 4) przedstawiać przewidywane skutki społeczne, gospodarcze, finansowe i prawne, 5) wskazywać źródła finansowania, jeżeli projekt ustawy pociąga za sobą obciążenie budżetu państwa lub budżetów jednostek samorządu terytorialnego, 6) przedstawiać założenia projektów podstawowych aktów wykonawczych, 7) zawierać oświadczenie o zgodności projektu ustawy z prawem Unii Europejskiej albo oświadczenie, że przedmiot projektowanej regulacji nie jest objęty prawem Unii Europejskiej”. Jak widać, unormowania regulaminu sprawiają, że uzasadnienie pełni ważną rolę w procesie legislacyjnym. Treść uzasadnienia w zestawieniu z tekstem ustawy pozwala ocenić najważniejsze jej cechy. Niestety zdarza się niekiedy, że uzasadnienie w istotnych kwestiach nie odpowiada warunkom wskazanym w Regulaminie Sejmu ${ }^{22}$.

Do zasad podatkowych mających największe znaczenie z punktu widzenia praw podatnika należy zasada pewności. Zalicza się ją do zasad techniki podatkowej, ale jej znaczenie daleko wykracza poza techniczne aspekty opodatkowania. Pewność i bezpieczeństwo prawne podatnika ściśle wiążą się z zakresem czasowym działania ustawy, czy szerzej - przepisów podatkowych. Jak pisze A. Gomułowicz, zasada lex retro non agit „musi być jednym z fundamentów prawodawstwa podatkowego"23. W Polsce od 1993 r. „ugruntowała się praktyka interpretacji istoty demokratycznego państwa prawnego jako zespołu zasad, zawierających m.in. takie zasady, jak lex retro non agit czy ochrona praw nabytych" ${ }^{24}$. Niemały jest w tym zakresie dorobek Trybunału Konstytucyjnego (TK). Dziś, po tym, co stało się w Polsce z TK ${ }^{25}$, problematyka zasady lex retro non agit $\mathrm{w}$ prawie podatkowym $\mathrm{w}$ odniesieniu do konkretnych rozwiązań jest podejmowana w literaturze ${ }^{26}$. W Niemczech

${ }^{22}$ W. Nykiel, Nowe przepisy dotyczace klauzuli przeciw unikaniu opodatkowania - wybrane aspekty legislacyjne, [w:] Współczesne problemy prawa podatkowego. Teoria i praktyka. Ksiega jubileuszowa dedykowana Profesorowi Bogumiłowi Brzezińskiemu, t. 1, Warszawa 2019, s. 388 i n.

23 A. Gomułowicz, Zasady podatkowe..., s. 30.

${ }^{24}$ J. Oniszczuk, Podatki i inne daniny $w$ orzecznictwie Trybunału Konstytucyjnego, Warszawa 2001 s. 107; W. Łączkowski, Zasada lex retro non agit jako problem konstytucyjny w orzecznictwie Trybunału Konstytucyjnego, [w:] Sądownictwo konstytucyjne, „Studia i Materiały" t. 2, z. 1, Warszawa 1996, s. 71-72.

25 Oświadczenie sędziów Trybunału Konstytucyjnego w stanie spoczynku, https:// prawo.gazetaprawna.pl/artykuly/1453307, oswiadczenie-22-sedziow-tk-w-staniespoczynku.html (dostęp: 30.12.2020).

${ }^{26}$ Por. np. H. Filipczyk, Reguła intertemporalna klauzuli ogólnej przeciwko unikaniu opodatkowania w świetle standardów konstytucyjnych, „Przegląd Podatkowy” 2016, nr 9. 
od lat wiąże się zakaz działania prawa wstecz z Rechtsstaatsprinzi $p^{27}$. Podobne podejście można spotkać również $\mathrm{w}$ innych państwach, choć unormowania prawne i orzecznictwo cechuje pewien stopień zróżnicowania ${ }^{28}$. Należy podkreślić, że zasada lex retro non agit jest elementem kultury prawnej współczesnych państw i ma chronić zaufanie do stanowionego prawa.

Podatnik, a w szczególności podatnik prowadzący działalność gospodarczą, planuje swoje transakcje często w okresach kilkuletnich, co ma duże znaczenie dla rozwoju gospodarczego. Działanie prawa podatkowego wstecz uniemożliwiałoby takie planowanie i tworzenie jakichkolwiek długofalowych koncepcji rozwoju. Niszczyłoby także zaufanie do państwa i funkcjonującego w tym państwie prawa.

Jak wyżej wskazano, TK zasadę ochrony praw nabytych lokował w ramach formuły demokratycznego państwa prawa. Takie rozumienie owej zasady Trybunał potwierdził na gruncie Konstytucji RP z 1997 r. W tej samej formule demokratycznego państwa prawa TK osadził zasadę zabezpieczenia interesów podatnika w toku. „Zasada zaufania obywatela do państwa i do stanowionego przez nie prawa nakazuje ustawodawcy należyte zabezpieczenie interesów w toku, a zwłaszcza należytą realizację uprawnień nabytych na podstawie poprzednich przepisów" ${ }^{29}$. To stanowisko również zostało potwierdzone po wejściu w życie Konstytucji RP.

Dla podatnika duże znaczenie ma ponadto vacatio legis, czyli okres, który ma upłynąć między ogłoszeniem ustawy a dniem jej wejścia w życie. Okres ten powinien być wystarczająco długi, by podatnik mógł się przygotować na zmianę unormowań. W tym miejscu warto przypomnieć, że Trybunał Konstytucyjny w orzeczeniu z dnia 29 marca 1994 r. (sygn. K 13/93) wskazał, iż ustawodawstwo podatkowe odnoszące się do podatków uiszczanych rocznie „powinno być tworzone nie tylko z respektowaniem zasady niedziałania prawa wstecz, lecz także przy zachowaniu stosownej vacatio legis w roku poprzedzającym rok podatkowy. Podatnicy powinni mieć czas na dostosowanie swoich decyzji do podatku, który będą musieli zapłacić w nadchodzącym roku podatkowym" 30 .

27 D. Birk, Steuerrecht, Heidelberg-München-Landsberg-Frechen-Hamburg 2011, s. 52 .

28 V. Thuronyi, Comparative Tax Law, The Hague-London-New York 2003, s. 76 i n.

29 J. Oniszczuk, Podatki i inne daniny..., s. 121.

30 Ibidem, s. 115. 
3. Wyżej przeprowadzone krótkie rozważania, mające jedynie sygnalizacyjny charakter, bez wątpienia dowodzą, że szeroko rozumiane procesy stanowienia prawa podatkowego mają olbrzymi wpływ na prawa podatnika i ich ochronę. Taki stan rzeczy prowadzi do wniosku, że procesy te winny być brane pod uwagę $\mathrm{w}$ analizach naukowych praw podatnika i ich funkcjonowania, w budowaniu katalogów tych praw i wreszcie w przygotowywaniu projektów aktów prawnych, a w szczególności projektu ustawy mającej charakter karty praw podatnika.

Na zakończenie warto podkreślić, że projekt ustawy Karta Praw Podatnika (druk nr 137), o którym była mowa w opracowaniu, niemało miejsca poświęca stanowieniu prawa podatkowego. W myśl unormowań zawartych w projekcie konsultacje przepisów prawa podatkowego są obowiązkowe, a odnosi się to również do projektów poselskich. Rządowe założenia i projekty przepisów prawa podatkowego są publikowane. W projekcie jest także przepis głoszący, iż prawo nie działa wstecz, chyba że na korzyść podatnika. Podatnika ma chronić odpowiednia vacatio legis. Ma on prawo do ochrony praw nabytych i interesów w toku. Ma również prawo do jasnego i zrozumiałego prawa podatkowego. W związku z tym chroni go też zasada in dubio pro tributario, a niezrozumiały przepis nie może być podstawą stosowania sankcji.

Obserwacja praktyki dowodzi, że takie przepisy są potrzebne, gdyż z jednej strony przyczyniłyby się do poprawy jakości naszego prawa podatkowego oraz umożliwiły odpowiednie wyważenie interesu publicznego i prywatnego, z drugiej zaś do wzmocnienia ochrony praw podatnika.

\section{BIBLIOGRAFIA}

Baker P., Taxpayers' Charters and a Taxpayers' Charter for Europe, [w:] Protection of Taxpayer's Rights, European, International and Domestic Tax Law Perspective, red. W. Nykiel, M. Sęk, Warszawa 2009.

Baker P., Pistone P., Taxpayers' Rights, General Report, IFA 2015.

Bentley D., Taxpayers' Rights: Theory, Origin and Implementation, Kluwer Law International 2007.

Birk D., Steuerrecht, Heidelberg-München-Landsberg-Frechen-Hamburg 2011.

Brzeziński B., Koncepcja praw podatnika i ich ochrony jako przedmiot badań naukowych, „Kwartalnik Prawa Podatkowego” 2005, nr 1.

Brzeziński B., Prawo podatkowe. Zagadnienia teorii i praktyki, Toruń 2017.

Brzeziński B., Nykiel W., Zasady ogólne prawa podatkowego, „Przegląd Podatkowy” 2002, nr 3.

Filipczyk H., Reguła intertemporalna klauzuli ogólnej przeciwko unikaniu opodatkowania w świetle standardów konstytucyjnych, „Przegląd Podatkowy” 2016, nr 9. 
Gomułowicz A., Zasady podatkowe wczoraj i dziś, Warszawa 2001.

Jędrzejewska K., Prof. Bralczyk: Fiskus oblewa egzamin z języka polskiego (wywiad), Gazeta Prawna.pl, 17.09.2018.

Kmieciak Z., Procesowe gwarancje ochrony interesu podatnika, „Kwartalnik Prawa Podatkowego" 2000, nr 1.

Kosikowski C., Ustawa podatkowa, Warszawa 2006.

Łączkowski W., Zasada lex retro non agit jako problem konstytucyjny w orzecznictwie Trybunału Konstytucyjnego, [w:] Sądownictwo konstytucyjne, „Studia i Materiały”, t. 2, z. 1, Warszawa 1996.

Mariański A., Rozstrzyganie wątpliwości na korzyść podatnika. Zasada prawa podatkowego, Warszawa 2011.

Mastalski R., Tworzenie prawa podatkowego a jego stosowanie, Warszawa 2015.

Nykiel W., Nowe przepisy dotyczace klauzuli przeciw unikaniu opodatkowania - wybrane aspekty legislacyjne, [w:] Współczesne problemy prawa podatkowego. Teoria i praktyka. Księga jubileuszowa dedykowana Profesorowi Bogumiłowi Brzezińskiemu, t. 1, Warszawa 2019.

Nykiel W., Sęk M., Standards, Trends and Challenges of National Tax Legislation, [w:] Tax Legislation. Standards, Trends and Challenges, red. W. Nykiel, M. Sęk, Warszawa 2015.

Oniszczuk J., Podatki i inne daniny w orzecznictwie Trybunału Konstytucyjnego, Warszawa 2001.

Serwacki J., Polityka podatkowa, [w:] Prawo podatkowe. Teoria. Instytucje. Funkcjonowanie, red. B. Brzeziński, Torun 2009.

Sęk M., Karta Praw Podatnika w polskim systemie podatkowym w świetle doświadczeń zagranicznych, „Kwartalnik Prawa Podatkowego” 2018, nr 1.

Strawiński P., Compliance. Prowadzenie biznesu w Polsce to brawura (wywiad z prof. A. Mariańskim, przewodniczącym Krajowej Rady Doradców Podatkowych), „Forbes”, 26.03.2020.

Thuronyi V., Comparative Tax Law, The Hague-London-New York 2003.

Wilk M., Potrzeba wprowadzenia Karty Praw Podatnika w Polsce, „Kwartalnik Prawa Podatkowego" 2018, nr 1.

Wróblewski J., Zasady tworzenia prawa, Warszawa 1989.

\section{TAXPAYER'S RIGHTS AND TAX LAW MAKING - SELECTED ISSUES}

Summary. The proper functioning of the state's financial mechanisms requires efficient financial policy, including tax policy. The predictability of changes in tax law implementing a policy known to taxpayers is consistent with the principle of legal certainty, as it significantly reduces the negative consequences of instability.

As is known, meetings of the Sejm and Senate are public. However, draft tax law provisions and even assumptions preceding these drafts should also be public. On the one hand, this would enable, or at least significantly facilitate, appropriate public consultations, and on the other, it would reduce taxpayers' uncertainty about future law. In the course of work on the draft, care should be taken to ensure the correctness of the legal language and to respect the principles of legislative technique. Consulting and issuing opinions on draft tax provisions by various entities, including experts, is of great importance for legislative works. Consultations with the participation of taxpayers, representatives of social, self-government and economic organizations as well as professional 
self-governments have an impact on the quality of law and promote the proper balance of public and private interests in tax law.

In the event of an incomprehensible provision, the taxpayer should be protected by the in dubio pro tributario rule. Such a provision cannot be the basis for applying sanctions to the taxpayer.

One of the most important tax principles from the point of view of taxpayer's rights is the principle of certainty. The taxpayer's legal certainty and security is closely related to the lex retro non agit principle. The principles of protecting acquired rights and protecting ongoing interests are also important.

It is worth emphasizing that the draft Taxpayers' Rights Act recently introduced to the Sejm, devotes quite a lot of attention to the provisions on tax law making.

Observation of practice proves that such provisions are needed because they would contribute to improving the quality of our tax law on the one hand and strengthening the protection of taxpayers' rights on the other.

Keywords: taxpayers' rights, charter for taxpayer's rights, tax law legislation, legislation, legislation principles 